\title{
Determination of the Anxiety Levels of Postgraduate Students who are Receiving Digital Scenario Supported Education towards Scientific Research
}

\author{
Determinación de los niveles de ansiedad de los estudiantes de \\ posgrado que reciben escenarios digitales Educación apoyada hacia \\ la investigación científica
}

\author{
Tahir Tavukcu \\ Near East University. Nicosia, Cyprus \\ tahir.tavukcu@neu.edu.tr
}

\begin{abstract}
In this study, it was aimed to determine the anxiety of postgraduate students who are receiving digital scenario supported education towards scientific research. The research was a quantitative study and the experiment and control group were designed according to the pre-test and post-test research model. In both groups, the courses were carried out in the form of blended learning (distance education and face to face) via the NEU-DEC (Near East University - Distance Education Centre) system. The experiment group was also supported by digital scenarios. The course materials were shared on the system with each group created in the special section. The distance education courses were carried out synchronously and asynchronously: it was possible with the Big Blue Button virtual classroom plugin when it was synchronous; when it was asynchronous, it was possible with the repetition of the courses that are recorded on the system when requested and also with the chat panel. In both groups, there were 40 postgraduate students from the programmes affiliated to institutes in Near East University. As a result of the success test applied as a pre-test before the study, the groups were assigned with the homogeneity as the test group with the last number being the odd number according to the school numbers in terms of achievement and gender. An anxiety scale for scientific research for collecting the required data was used with the necessary permission. The obtained data were analysed by appropriate analysis techniques. Findings obtained from this research revealed that, at the end of the application, the students' -both in experiment and control group- levels of anxiety related to scientific research decreased. Although there was no statistically significant difference between the groups, it was determined that the average level of anxiety of the experimental group supported by digital scenarios decreased more than the ones in the control group. According to this result, it can be said that the education given with digital scenarios had a positive effect of reducing students' anxieties about research.
\end{abstract}

\footnotetext{
Keywords

Blended learning, scenario based / supported education, digital scenario, virtual classroom, scientific research, anxiety.
}

\section{Resumen}

En este estudio, se buscó determinar la ansiedad de los estudiantes de posgrado que reciben educación basada en escenarios digitales hacia la investigación científica. La investigación fue un estudio cuantitativo y el experimento y grupo de control fueron diseñados de acuerdo con el pre-test y el modelo de investigación post-prueba. En ambos grupos, los cursos se llevaron a cabo en forma de aprendizaje mixto (educación a distancia y cara a cara) a través del sistema NEU-DEC (Near East University). El grupo 


\begin{abstract}
de experimentos también fue apoyado por escenarios digitales. Los materiales del curso se compartieron en el sistema con cada grupo creado en la sección especial. Los cursos de educación a distancia se llevaron a cabo de forma síncrona y asincrónica: era posible con el plugin del aula virtual Big Blue Button cuando era síncrono; Cuando era asíncrono, era posible con la repetición de los cursos que se registran en el sistema cuando se solicitaba y también con el panel de chat. En ambos grupos, había 40 estudiantes de postgrado de los programas afiliados a los institutos de la Universidad del Cercano Oriente. Como resultado de la prueba de éxito aplicada como un pre-test antes del estudio, los grupos fueron asignados con la homogeneidad como el grupo de prueba con el último número siendo el número impar de acuerdo a los números de la escuela en términos de logro y género. Se utilizó una escala de ansiedad para la investigación científica para recolectar los datos requeridos con el permiso necesario. Los datos obtenidos se analizaron mediante técnicas de análisis apropiadas. Los hallazgos obtenidos de esta investigación revelaron que, al final de la aplicación, disminuyeron los niveles de ansiedad de los estudiantes, tanto en el grupo experimental como en el grupo control. Aunque no hubo diferencias estadísticamente significativas entre los grupos, se determinó que el nivel medio de ansiedad del grupo experimental soportado por escenarios digitales disminuyó más que los del grupo control. De acuerdo con este resultado, se puede decir que la educación dada con escenarios digitales tuvo un efecto positivo de reducir las ansiedades de los estudiantes acerca de la investigación.
\end{abstract}

\title{
Palabras clave
}

Aprendizaje combinado, educación basada en escenarios / apoyado, escenario digital, aula virtual, investigación científica, ansiedad.

\section{Introduction}

Anxiety in contemporary human beings is a reaction to various destructive, disruptive situations directed at the individual's own being or the things s/he identifies. In addition to its positive nature, it is destructive and disruptive as it reaches pathological dimensions (Canbaz, Sünter, Aker and Peşken, 2007). As a result, anxiety can result in unpleasant emotional states accompanied by physiological symptoms (Feist, 1990). Anxiety, which is a feeling related to fear, can also be caused by unpleasant fantasies as well as real causes (İnanç, Bilgin and Atıc1, 2007); but anxiety and fear are not the same emotions. Fear is a natural feeling. Anxiety is a complex feeling of unknown origin (Başaran, 2015).

Anxiety is the state of excitement that brings transient and discouraging attitudes, or exaggerated situations, instead of overturning emotional and intellectual equilibrium. Anxiety and worry vary in intensity, and anxiety means more intense emotion. Anxiety based on some reason is that a certain danger has been determined indefinitely or precisely. Anxiety arises from the identification of the instability and the threat between the individual's ability to control danger and the ability to fight it (Le Gall, 2006). Anxiety is a state of extreme arousal manifested by physical, emotional, and mental changes that a person experiences when faced with a stimulus.

Research anxiety arises with the behaviours and feelings like not doing research if the one does not have to do so, being bored when research is needed, being uncomfortable with the idea of doing research, being restless while doing research, not believing in himself or herself while doing research (Çokluk-Bökeoğlu and Y1lmaz, 2005). In the

Determination of the Anxiety Levels of Postgraduate Students who are Receiving Digital Scenario Supported Education towards Scientific Research. Tahir Tavukcu.

Página 2 de 10 
research conducted by Büyüköztürk (1997), the attitudes of university students towards research production were found to be negative. Tekin (2007) found that students who received post-graduate education had a high research anxiety and that their level of research proficiency decreased as students' anxiety levels increased.

It is considered that having sufficient knowledge and skills, self-confidence and low concerns for the effectiveness of the scientific research will enhance the success.

The anxiety levels were examined according to age, gender, occupation and education level in the study of determining the concerns towards the scientific research applied to the postgraduate students. Looking at the study as a whole, it can be seen that the level of anxiety related to research was low for students who were studying at the postgraduate level. While there was no significant difference according to age, gender, education level, the research assistant students were found to be much less anxious than the other students (Bayar, SA, Bayar, V., Eğmir, E., Kayır, G. and Ödemiş, İ. S., 2013).

In the study of Çelik, Önder, Durmaz, Yurdusever and Uysal (2014), "Nursing Students' Anxiety and Attitudes towards Scientific Research" were intended to be determined. As a result of the study, it was determined that nursing students' anxiety levels were moderate and their attitudes were positive (Aydın, Adıgüzel and Topal, 2015). In addition, the anxiety scores of the students who did not take the statistics courses were higher, although there was no significant difference between the state of taking the statistics courses and the anxiety situations previously.

In the study of Soykan (2015) ' Views of Students', Teachers' and Parents' on the Tablet Computer Usage in Education", the most important concerns of the parents were that students were more likely to devote time to game than their lessons and had some worries that they would not be able to respond if they were asked questions at some point by their children. In other studies, however, teachers and prospective teachers had some worries about the use of new technologies at the beginning of the study and after the application, they had the conclusion that they did not have any worries and these technologies had a positive impact on their views and achievements at the end of the research (Bicen \& Kocakoyun, 2017; Sert \& Boynueğri, 2017; Uzunboylu, Hürsen, Özütürk \& Demirok, 2015).

In many studies, there is a concern and anxiety over the use of new technologies during the integration of new technologies into the education. This concern, anxiety and motivation which emerged before applying new technologies to the target group, alters to a positive outlook after the application (Read \& Kukulska-Hulme, 2015; Bicen ve Uzunboylu, 2013).

The changes and developments in technology have influenced the scientists in a positive way. If we look at some of them; it was necessary to spend a lot of time in the libraries to do research in the past. Also, the fact that the resources were quite outdated had a direct impact on the effectiveness and validity of the work. However, with the continuous development of technology, especially with the rapid development of computer and internet technologies, the one do not experience those problems. Besides, it should be investigated whether the researchers' anxiety levels have changed in a 
positive or negative way with the developing technology. When we look at the literature, it can be seen that the number of studies conducted in Turkey and Cyprus in order to determine this has been rather low in the recent years.

\section{Purpose of the research}

The purpose of this research was to determine whether there is a difference between the anxiety levels of the experimental group (in the form of blended learning) that was supported by digital scenarios and the control group (in the form of blended learning) towards scientific research according to the pre-test and post-test results of the groups.

\section{Method}

\section{Working group}

Post-graduate (Master and Ph.D.) students in Near East University created the study group of this research. Students in the study group are volunteers from different programmes. In addition, the participant students were required to carry out scientific research such as theses and articles the students who are going to participate the research were required to do scientific research (thesis, article, paper) before and to take the course of Scientific Research Methods. There are 40 postgraduate students from different programmes both in experimental and control groups. According to the students' numbers, the odd numbers of the last digit are assigned to the control group and the even numbers are assigned to the experiment group. As a result of the achievement test that was applied as a pre-test at the beginning of the study, it was determined that, it was homogeneous in terms of success and sex.

\section{Development of Educational Environment}

The study was carried out by creating different systems for the two groups via Near East University Distance Education Center system (Moodle). For both groups, the BigBlueButton virtual classroom environment, sharing the lecture notes, video sharing and digital scenarios for the experimental group were applied on the Moodle system. 


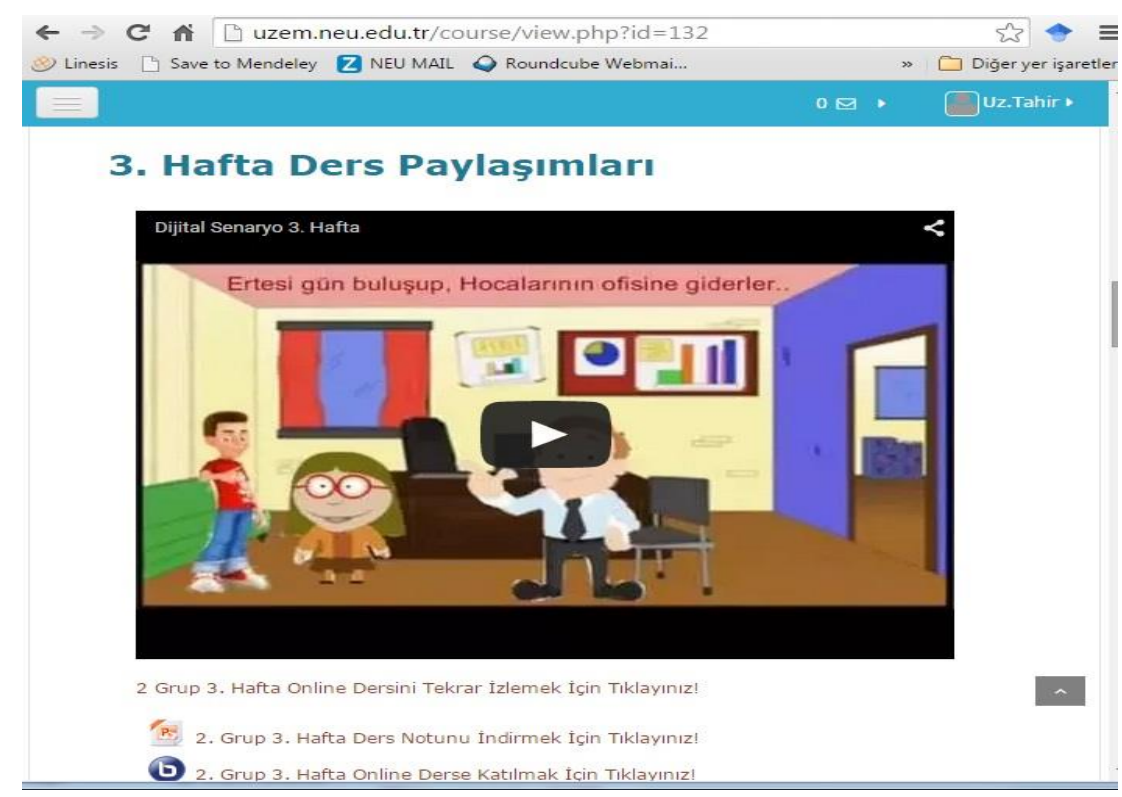

Figure 1. Sharing of the digital scenarios in the course system

\section{Application}

The application was carried out for 9 weeks. All materials related to the course were delivered through "Course of Scientific Research and Ethics in Educational Administration" prepared by Moodle through NEU-DEC system. The environments of the control and experimental groups were separated by different input fields and everyone were able to access their own group system. Checking the online course attendance of the students in both groups was controlled via the Moodle system and the entry / exit times of all students were controlled. In addition, the inputs and outputs to the system were controlled using the same method for monitoring Digital Scenarios applied to the experimental group. File sharing from the web 2.0 tools in the system, Big Blue Button virtual classroom environment, saved online video tutorials, various video links added to YouTubes, and links to digital scenarios added on YouTube to the experimental group were shared as labels. Many features of the Big Blue Button virtual classroom were used in online lessons. Features like file sharing that allows students to see and emphasize those, sharing screens, communicating instantly with voice and text were actively used. In this way, they had the chance to ask instant questions to the teacher and to the other students. In addition, online courses were recorded and added to the new system so that they can be viewed at any time. Writing messages and notifying asynchronously were used by adding the asynchronous chat panel. Project delivery was via e-mail.

\section{Data Collection Tool}

"The Anxiety Scale Towards the Scientific Research" which was developed by Büyüköztürk in 1997 to measure the research anxieties of the university students was used to determine whether there were any differences between the anxiety levels of the scientific researchers before and after the study in the experimental and control groups participating the research. The scale consists of 12 items and it has one factor. The 
Croanbach Alpha value is .872. Five-point likert scale consisting of "strongly agree", "agree", "undecided", "disagree" and "strongly disagree" were used in the Anxiety Scale Towards the Scientific Research. The answers given to the items in the tool are scored by giving numerical values to the score from 5 to 1 as the "totally agree" to the "totally disagree" in the expressions that directly reflect the anxiety state and thus the high score from the scale shows high anxiety and low score from the scale shows low anxiety. In this study, the scale's croanbach alpha value is .881 .

\section{Results}

Repeated Measure Anova Test was applied in order to determine whether the students' "anxiety levels for research" showed some differences before and after the course from group to group. Accordingly, it was determined that there was no significant difference between the experimental and control groups $(\mathrm{F} 1,78=2.932, \mathrm{p}>0.05)$, although the anxiety levels of the research were positively changed in the pre-test post-test scores in both groups.

Table 1.

Control and Experimental group's level of anxiety for research

\begin{tabular}{|c|c|c|c|c|c|c|c|c|c|}
\hline \multirow{4}{*}{$\begin{array}{c}\text { Anxiety } \\
\text { level }\end{array}$} & & \multicolumn{3}{|c|}{ Experimental } & \multicolumn{2}{|c|}{ Control } & $\mathbf{F}$ & $\mathbf{P}$ & Statement \\
\hline & & $\mathbf{N}$ & $\overline{\mathbf{x}}$ & SS & $\overline{\mathbf{x}}$ & SS & \multirow{3}{*}{2.932} & \multirow{3}{*}{.091} & \multirow{3}{*}{$\mathrm{p}>0.05$} \\
\hline & Pre-test & 40 & 3.11 & .59 & 3.12 & .49 & & & \\
\hline & Post-test & 40 & 2.69 & .50 & 2.99 & .53 & & & \\
\hline
\end{tabular}

As shown in Table 1, the mean of the pre-test score of students in the experimental group was $\overline{\mathbf{X}}=3.11(\mathrm{SD}=.59)$ while the mean of the post-test score was $\square$ $=2.69(\mathrm{SD}=.50)$. For the control group, the mean of the pre-test score was $\overline{\mathbf{X}}=3.12$ $(\mathrm{SD}=.49)$ while the mean of the post-test score was $\overline{\mathbf{X}}=2.99(\mathrm{SD}=.53)$. It can be seen that although there was no significant difference between the pre-test and post-test scores of the groups, it was concluded that there is a decrease in the level of anxiety towards the research. The chart for these results is shown below (Chart 3). 


\section{Graph 1.}

Pre-test post-test recording levels of experimental and control groups

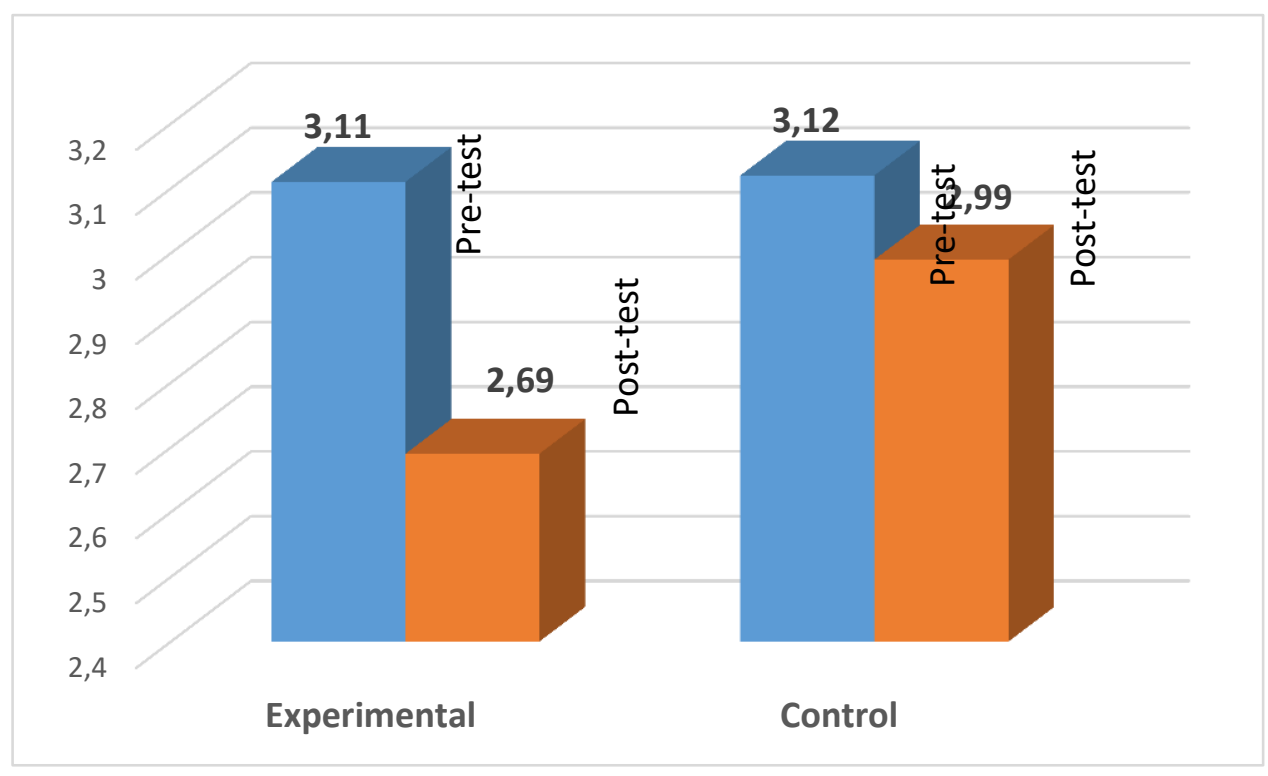

When we look at the pre-test and post-test comparisons of the anxiety scale items, although there is not any significant difference between those expressions: "I feel squeezed when I have to do research" $\left(\overline{\mathbf{X}}_{\ddot{O}}=3.21, \overline{\mathbf{X}}_{\mathrm{S}}=2.24\right)$, "Even the word 'research' is enough to make me uneasy" $\left.\overline{\mathbf{X}}_{\ddot{O}}=2.90, \overline{\mathbf{X}}_{\mathrm{S}}=2.07\right)$, "The idea of doing research makes me uncomfortable" ( $\left.\overline{\mathbf{X}}_{\ddot{O}}=2.84, \square_{S}=2.11\right)$, "I usually feel uneasy when I am doing research $\left(\overline{\mathbf{X}}_{\ddot{O}}=2.94, \overline{\mathbf{X}}_{\mathrm{S}}=2.24\right)$ " and "I get bored in a short while I am doing research $\left(\overline{\mathbf{X}}_{\ddot{O}}=2.84, \overline{\mathbf{X}}_{\mathrm{S}}=2.22\right)$ ", it can be seen that there is a decrease in the pre-test post-test scores.

\section{Conclusion and Discussion}

It was determined that after the application, the experimental and the control group students' levels of anxiety towards scientific research decreased although there was no statistically significant difference. The result is that the average of anxiety of students in the experimental group supported by digital scenarios decreased more than the level of anxiety in the control group. According to this result, it can be said that the education given with digital scenarios has a positive effect of reducing the students' anxieties towards research.

According to the findings, it can be seen that after study, the anxieties of the students in both groups are lower than their anxieties before the study. It can be thought that one of the reasons is that they use the technology more effectively after the application and digital scenarios provide more permanent learnings. 
There are studies in the literature which show consistency with the study results. Saracaloğlu (2008) showed that the research anxiety of the postgraduate students was low. This result is consistent with the result of this present study. Unlike these results, Çelik, Önder, Durmaz, Yurdusever and Uysal (2014) stated that the nursing department students had a moderate level of concern towards scientific research. Yilmaz and Çokluk (2010) stated that the degrees of research anxiety of graduates of science and literature faculty are not high. Konokman, Yelken and Yokuş (2015) found out that the anxiety levels of the prospective students towards scientific research is low, and there is a significant difference according to class levels. When we look at the recent studies, in the study of Aslan and Karagül (2017) "Anxiety Levels of Graduate Students in Turkish Language Education Programme about Carrying out Scientific Research", it can be seen that the anxiety levels were generally moderate. In addition, they found out that male students were more anxious about carrying out scientific research compared to female students. In general, it can be seen that the results of the research show similarities to many researches in the literature. By considering the results of the study, it is recommended to extend the use of digital scenarios in different age groups and lectures as a support for blended education.

Presentación del artículo: 15 de Febrero de 2017 Fecha de aprobación: 15 de marzo de 2017 Fecha de publicación: 31 de marzo de 2017

Tavukcu, T. (2017). Determination of the Anxiety Levels of Postgraduate Students who are Receiving Digital Scenario Supported Education towards Scientific Research.. RED. Revista de Educación a Distancia, 53. Consultado el (dd/mm/aaaa) en http://www.um.es/ead/red/53/tavikcu.pdf

\section{References}

Aslan, C., \& Karagül, S. (2017). Anxiety levels of graduate students in Turkish language education programme about carrying out scientific research. Mehmet Akif Ersoy University Journal of Education Faculty, 1(38), 201-217.

Aydın, Y., Adıgüzel, A., \& Topal, E. A. (2015). Determining the attitudes of midwives and nurses toward scientific research. Journal of Human Rhythm, 1(4). 168-175.

Başaran, İ. E. (2015). Educational psychology. Theory and practice. Ankara: Nobel.

Bayar, S. A., Kayır, G., Eğmir, E., Ödemiş, İ. S. \& Bayar, V. (2013). Views of graduate students on research ethics. VI. National Graduate Education Symposium, 118123. 
Bicen, H., \& Uzunboylu, H. (2013). The use of social networking sites in education: A case study of Facebook. Journal of Universal Computer Science (J. UCS), 19(5), 658-671.

Bicen, H. \& Kocakoyun, S. (2017). Determination of university students' most preferred mobile application for gamification. World Journal on Educational Technology: Current Issues. 9(1), 18-23.

Büyüköztürk, Ş. (1997). Developing anxiety scale towards scientific research. Educational Administration. 3(4). 453-464.

Canbaz, S., Sürter, A. T., Aker, S. V \& Peksen, Y. (2007). The anxiety level of the interns in a medical faculty and affecting factors. Journal of General Medical, 17 (1), 15-19.

Çelik S., Önder G., Durmaz K., Yurdusever Y. \& Uysal N. (2014) Determination of anxiety and attitude towards doing scientific research of nursing students. Journal of Health Science and Profession-HSP. 1(2), 23-31.

Çokluk-Bökeoğlu, Ö. \& Yılmaz, K. (2005). The relationship between attitudes of university students towards critical thinking and research anxieties. Educational Administrator: Theory and practice, 11 (41), 47-67.

Feist, J. (1990). Theories of Personality. Worth, TX: Holt, Rinehart, and inston.

İnanç, B. Y., Bilgin, M. \& Atıcı, M. K. (2007). Developmental psychology. Ankara: Pegem A.

Konokman, G. Y., Yelken, T. \& Yokuş, G. (2015). Preschool Teacher Candidates' Research Qualifications and Anxiety Level towards Research. Eurasian Journal of Educational Research, 60, 57-74.

Le Gall, A., (2006), Anxiety and concern, (Trans:İ.Yerguz). Ankara: Dost Bookshop.

Read, T., \& Kukulska-Hulme, A. (2015). The role of a mobile app for listening comprehension training in distance learning to sustain student motivation. Journal of Universal Computer Science (J. UCS), 21(10), 13271338.

Saracaloğlu, A. S. (2008). The relationship between post graduate students' academic motivation level, research anxiety and attitudes with their research competence. Yüzüncü Yll University Journal of the Education Faculty, 5(2), 179208.

Sert, N. \& Boynuegri, E. (2017). Digital technology use by the students and englishteachers and self-directed language learning. World Journal on Educational Technology: Current Issues. 9(1), 24-34.

Soykan, E. (2015). Views of students', teachers' and parents' on the tablet computer usage in education. Cypriot Journal of Educational Sciences. 10(3), 228-244.

Tekin, M. (2007). Research anxiety levels of faculty of arts and science graduates. Abant İzet Baysal University Journal of Education Faculty. 16(Special Issue: Ipekyolu), 2144-2152.

Determination of the Anxiety Levels of Postgraduate Students who are Receiving Digital Scenario Supported Education towards Scientific Research. Tahir Tavukcu. 
Uzunboylu, H., Hürsen, Ç., Özütürk, G., \& Demirok, M. (2015). Determination of Turkish University Students' Attitudes for Mobile Integrated EFL Classrooms in North Cyprus and Scale Development: ELLMTAS. Journal of Universal Computer Science (J. UCS), 21(10), 1283-1296.

Yılmaz, K., \& Çokluk, Ö. (2010). Research anxiety levels of faculty of arts and science graduates. Abant İzzet Baysal University Journal of Education Faculty, 10(1), $1-9$. 